\title{
HUBUNGAN TINDAKAN IBU TERHADAP KEJADIAN DIARE PADA BALITA KECAMATAN ANREAPI KABUPATEN POLEWALI MANDAR
}

\author{
Dewi Ratnasari ${ }^{1}$, Patmawati $^{2}$ \\ ${ }^{1}$ Kampus Universitas Al Asyariah Mandar, Fakultas Kesehatan Masyarakat. \\ J1. Budi Utomo No.2 Manding, Kecamatan Polewali, Kabupaten Polewali Mandar, Provinsi \\ Sulawesi Barat, Indonesia.
}

E-mail: dewiratnasari339@yahoo.com

\begin{abstract}
RELATIONSHIP OF MOTHER ACTIONS TO DIARRY EVENTS AT THE VILLAGE IN THE VILLAGE OF THE SUPPLEMENT DAMAGE OF REGENCY OF POLEWALI MANDAR IN 2018
\end{abstract}

\begin{abstract}
Diarrhea is one of the major causes of illness and death in almost all developing countries. All age groups can be attacked by diarrhea but severe illness with death occurs in infants. This study aims to find out the Relationship Measures Mother Against Diarrhea Occurrence in Toddlers In Village Duampanua District Anreapi Polewali Mandar Regency. This type of research is quantitative using cross sectional design to 70 mothers as selected sample using cluster sampling. Data analysis with univariate to describe characteristic of respondent and bivariate by using chi square test. The results showed that respondents who use clean water sources to make milk formula did not meet the requirements of more suffering from diarrhea that is $64.3 \%$ with $p$ value $=0.000$, respondents with sterilization of milk bottle is not good more diarrhea is $45.7 \%$ with $p$ value $=0.000$, and respondents with the way food presentation does not meet the requirement more diarrhea is 47,1\% with value $p$ value $=0,120$. Statistical analysis found that the source of clean water used to make milk formula and sterilization of milk bottles has a significant relationship with the incidence of diarrhea in toddlers, while the way of serving food, there is no significant relationship to the incidence of diarrhea in infants. Suggested to the user society of bottle milk in toddler is expected to always wash hands well and always pay attention to kesterilan baby toddler bottle to avoid toddler from risk of diarrhea occurrence.
\end{abstract}

Keywords: Mother's action, diarrhea in toddler.

\begin{abstract}
Abstrak
Diare merupakan salah satu penyebab utama kesakitan dan kematian hampir diseluruh negara berkembang. Semua kelompok usia bisa diserang diare tetapi penyakit berat dengan kematian terjadi pada balita. Penelitian ini bertujuan mengetahui Hubungan Tindakan Ibu Terhadap Kejadian Diare pada Balita Di Desa Duampanua Kecamatan Anreapi Kabupaten Polewali Mandar. Jenis penelitian ini adalah kuantitatif menggunakan desain cross sectional terhadap 70 ibu sebagai sampel yang dipilih menggunakan cluster sampling. Analisis data dengan univariat untuk mendeskripsikan karakteristik responden dan bivariat dengan menggunakan uji chi square. Hasil penelitian menunjukkan bahwa responden yang menggunakan sumber air bersih untuk membuat susu formula tidak memenuhi syarat lebih banyak yang menderita diare yaitu $64,3 \%$ dengan nilai $p$ value $=0,000$, responden dengan sterilisasi botol susu tidak baik lebih banyak mengalami diare yaitu $45,7 \%$ dengan nilai $p$ value $=0,000$, dan responden dengan cara penyajian makanan tidak memenuhi syarat lebih banyak mengalami diare yaitu $47,1 \%$ dengan nilai $p$ value $=0,120$. Analisis statistik diperoleh bahwa sumber air bersih yang digunakan untuk membuat susu formula dan sterilisasi botol susu terdapat hubungan yang signifikan dengan kejadian diare pada balita, sedangkan cara penyajian makanan, tidak ada hubungan yang signifikan terhadap kejadian diare pada balita. Disarankan kepada masyarakat pengguna botol susu pada balita diharapkan senantiasa mencuci tangan dengan baik dan selalu memperhatikan kesterilan botol susu balita guna menghindari balita dari resiko kejadian diare.
\end{abstract}

Kata kunci : Tindakan ibu, diare pada balita 


\section{PENDAHULUAN}

Di Negara berkembang penyakit diare merupakan masalah utama kesehatan masyarakat dengan angka kesakitan dan kematian yang tinggi. Setiap tahun diperkirakan 2,5 milyar kejadian diare terjadi pada balita. Berdasarkan publikasi World Health Organization (WHO), diare adalah buang air besar (BAB) dengan konsistensi lembek hingga cair dan frekuensi $>3$ kali sehari. Menurut data World Health Organization (WHO), diare adalah penyebab nomor satu kematian anak di bawah lima tahun (balita) di seluruh dunia yang mengakibatkan 842.000 kematian, 361.000 diantaranya merupakan balita (WHO, 2012).

Terjadinya diare pada balita tidak terlepas dari peran faktor tindakan ibu yang menyebabkan penyebaran kuman entrik terutama yang berhubungan dengan interaksi tindakan ibu dalam mengasuh balita dan faktor lingkungan dimana balita tinggal. Tindakan ibu yang menyebabkan penyebaran kuman entrik dan meningkatkan risiko terjadinya diare yaitu tidak memberikan ASI eksklusif secara penuh pada bulan pertama kehidupan, memberikan susu formula dalam botol susu, sterilisasi botol susu yang tidak benar, menggunakan air minum yang tercemar, tidak mencuci tangan pada saat memasak, saat makan atau sebelum menyuapi balita atau sesudah buang air besar dan sesudah membuang tinja balita (Depkes RI, 2009).

Hasil penelitian Nimas menunjukkan bahwa terdapat hubungan antara perilaku ibu yang meliputi pengetahuan, sikap dan tindakan ibu dengan kejadian diare pada balita. Semakin baik perilaku ibu (pengetahuan, sikap dan tindakan) maka semakin sedikit pula kejadian diare pada balita (Prita, Skripsi, 2014).

Status kesehatan balita dipengaruhi oleh tindakan ibu. Hal ini disebabkan karena balita tidak dapat menjaga dirinya dari agen-agen penyakit dan sangat bergantung pada pengasuhnya dimana pelaku utama yang berperan dalam mengasuh balita dalam rumah tangga di negara berkembang adalah ibu (Prita, Skripsi, 2014).

Menurut Notoadmodjo tindakan merupakan komponen yang penting yang menentukan perilaku kesehatan seseorang. Tindakan yang baik disebabkan oleh pendidikan, Pendidikan ibu berpengaruh terhadap tindakan pencarian fasilitas kesehatan balitanya dan aktif mengikuti penyuluhan karena ibu yang berpendidikan cenderung lebih menjaga kesehatan dan kebersihan balitanya (Notoatmodjo, 2010).

Menurut Depkes RI bahwa diare adalah buang air besar lembek atau cair dapat berupa air saja yang frekuensinya lebih sering dari biasanya (biasanya tiga kali atau lebih dalam sehari) (Depkes RI, 2000). Menurut Widjadja Diare dapat diartikan sebagai buang air encer lebih dari empat kali sehari, baik disertai lendir dan darah maupun tidak (Widjaja, 2002).

Penyakit diare disebabkan oleh infeksi bakteri, virus dan parasit, dapat ditularkan melalui air dan makanan yang terkontaminasi kotoran manusia dan hewan, selain itu sumber air bersih, penanganan makanan dan kebersihan pribadi (Kementerian Kesehatan Republik Indonesia, 2011).

Penyakit diare merupakan penyakit endemis di Indonesia dan juga merupakan penyakit potensial KLB yang sering disertai dengan kematian. Pada tahun 2015 terjadi 18 kali KLB Diare yang tersebar di 11 provinsi, 18 kabupaten/kota, dengan jumlah penderita 1.213 orang dan kematian 30 orang (CFR 2,47\%) (Profil Kesehatan Indonesia ,2015).

Insiden dan period prevalence kasus diare untuk seluruh kelompok umur di Indonesia adalah 3,5\% dan 7,0\%. Insiden kasus diare pada kelompok usia balita di Indonesia adalah 10,2\%. Lima provinsi dengan insiden maupun period prevalen diare tertinggi adalah Papua, Sulawesi Selatan, Aceh, Sulawesi Barat, dan Sulawesi Tengah. Insiden diare pada kelompok usia balita di Indonesia adalah 10,2\%. (Riskesdas, 2013).

Setelah Pneumonia (17\%) Diare merupakan penyebab kematian balita nomor dua di dunia (16\%) Kematian pada balita meningkat sebesar $40 \%$ tiap tahun disebabkan oleh diare (Patmawati, jurnal, 2016).

Cakupan penemuan kasus diare di Puskesmas Anreapi mengalami peningkatan dengan jumlah kasus diare pada balita setiap tahunnya rata-rata di atas $40 \%$ dari jumlah cakupan penemuan penderita diare yaitu pada tahun 2015 sebesar $40 \%$ dan tertinggi di tahun 2016 sebesar 67,5\% (Data Puskesmas Anreapi, 2016).

Data profil Dinas Kesehatan Kabupaten Polewali Mandar tahun 2015 ditemukan jumlah penderita diare di puskesmas Anreapi sebanyak 588 kasus, kejadian diare pada balita sebanyak 232 kasus (40\%) dari jumlah penderita secara keseluruhan. Di usia $\quad 0-\leq 1$ tahun sebanyak 38 
balita, umur $1-4$ tahun sebanyak 194 balita (Dinkes Kabupaten Polewali Mandar, 2015).

Data profil Dinas Kesehatan Kabupaten

Polewali Mandar tahun 2016 ditemukan jumlah penderita diare di puskesmas Anreapi sebanyak 528 kasus, kejadian diare pada balita sebanyak 183 kasus $(67,5 \%)$ dari jumlah penderita secara keseluruhan. Di usia $0-\leq 1$ tahun yaitu 23 balita, umur $1-4$ tahun sebanyak 158 balita (Dinkes Kabupaten Polewali Mandar, 2016).

Berdasarkan data profil Dinas Kesehatan Kabupaten Polewali Mandar, Puskesmas Anreapi merupakan salah satu wilayah yang jumlah penderita diarenya mengalami peningkatan dari tahun 2015 sampai dengan 2016 yaitu sebanyak 40\% menjadi 67,5\% (Dinkes Kabupaten Polewali Mandar, 2016).

Data kasus diare di Puskesmas Anreapi yang tercatat pada bulan Januari sampai dengan Desember tahun 2017, tercatat 137 kasus diare pada balita. Desa Duampanua yaitu 61 kasus, kelurahan Anreapi sebanyak 36 kasus, Desa Kunyi sebanyak 28 kasus, Desa Pappandangan sebanyak 8 kasus dan Desa Kelapa Dua sebanyak 4 kasus (Data puskesmas Anreapi, 2017).

Hasil penelitian Sukardi, menunjukkan bahwa ada hubungan yang bermakna antara riwayat pemberian ASI eksklusif, kebiasaan mencuci tangan dan penggunaan botol susu dengan kejadian diare pada balita yang dipengaruhi oleh tidak diberikannya ASI eksklusif pada balita sejak umur 0-6 bulan, kebiasaan mencuci tangan yang buruk dan sterilisasi botol susu yang tidak benar (Sukardi, skripsi, 2016).

Menurut Notoatmodjo, berdasarkan kualitas fisik air bersih, syarat-syarat air minum yang bersih diantaranya yaitu memenuhi syarat fisik, tidak berwarna, tidak berasa dan tidak berbau. Sehingga dalam kehidupan sehari-hari cara mengenal air yang memenuhi persyaratan fisik tidak sukar (Notoatmodjo, 2003).

Hasil survey dan wawancara awal terhadap 7 KK (Kepala Keluarga) didapatkan hasil bahwa sumber air minum yang dikonsumsi warga berasal dari pegunungan dan juga sumur, rata- rata masyarakat tidak memasak terlebih dahulu air yang akan dikonsumsi. Kualitas fisik air di desa Duampanua keruh. Para ibu balita rata-rata tidak segera merendam botol susu dalam air bersih dan tidak mencuci botol susu menggunakan sabun dan air yang mengalir setelah digunakan, namun botol susu dibersihkan ketika akan digunakan kembali.

Berdasarkan uraian permasalahan yang telah diuraikan sebelumnya maka dinilai perlu dilakukan penelitian mengenai "Hubungan Tindakan Ibu Terhadap Kejadian Diare pada Balita di Desa Duampanua Kecamatan Anreapi Kabupaten Polewali Mandar Tahun 2018”.

\section{METODE PENELITIAN}

Jenis penelitian yang digunakan adalah penelitian dalam bentuk SurveyAnalitik yang bersifat Observasional dengan metode pendekatan Cross-Sectional. populasi dalam penelitian ini adalah seluruh ibu yang memiliki balita yang berusia 6 bulan sampai 60 bulan dan diberikan susu formula dan MP ASI (Makanan Pendamping Air Susu Ibu) serta tinggal di Desa Duampanua Kecamatan Anreapi Kabupaten Polewali Mandar. Cara pengambilan sampel dalam penelitian ini dengan menggunakan Random Sampling (Probability Samples) dengan teknik Cluster Sampling. Jumlah sampel sebanyak 70 responden.

Data primer diperoleh dengan cara melakukan wawancara langsung dengan menggunakan kuesioner yang telah tersedia yang memuat pertanyaan-pertanyaan maupun pernyataan-pernyataan yang digunakan untuk menggali informasi mengenai variabel-variabel yang akan dianalisis pada penelitian ini yang mana erat kaitannya dengan kejadian diare pada balita. Pengolahan data yang dilakukan meliputi editing, coding, entry dan tabulating. Analisis data yang dilakukan untuk penelitian ini menggunakan analisis univariat dan analisis bivariat. Tampilan data kategorik berupa frekuensi dan persentase dan analisis bivariat menggunakan uji chi square. Analisis data menggunakan program SPSS. 


\section{HASIL DAN PEMBAHASAN}

\section{Analisis Univariat}

Variabel Independen

Tabel 1

Distribusi Frekuensi Karakteristik Responden Dan Variabel Independen Di Desa Duampanua Kecamatan Anreapi Kabupaten Polewali Mandar Tahun 2018.

\begin{tabular}{lcc} 
KARAKTERISTIK & $\mathbf{n}$ & $\%$ \\
RESPONDEN & 33 & 47,1 \\
\hline Umur & 34 & 48,6 \\
19-29 Tahun & 3 & 4,3 \\
30-40 Tahun & & \\
41-50 Tahun & 63 & 90 \\
\hline Pekerjaan & 5 & 7,1 \\
Tidak Bekerja & 1 & 1,4 \\
Honorer & 1 & 1,4 \\
Wiraswasta & & \\
PNS & 2 & 2,9 \\
\hline Pendidikan & 21 & 30 \\
Tidak Sekolah & 21 & 30 \\
SD & 20 & 28,6 \\
SMP & 6 & 8,6 \\
SMA & & \\
Perguruan Tinggi & & \\
\hline Sibr: Da Pim, & & \\
\hline
\end{tabular}

Sumber : Data Primer, 2018

Data pada tabel 4.1 menunjukkan bahwa dari 70 responden, umur responden terbanyak terdapat pada umur 30-40 tahun yaitu sebanyak 34 orang $(48,6 \%)$, sedangkan yang paling sedikit yaitu pada umur 41-50 tahun sebanyak 3 orang $(4,3 \%)$.

\begin{tabular}{lcc}
\hline \multicolumn{1}{c}{ VARIABEL INDEPENDEN } & n & \% \\
\hline Sumber air bersih yang digunakan untuk membuat susu formula & \\
Memenuhi Syarat & 16 & 22,9 \\
Tidak Memenuhi Syarat & 54 & 77,1 \\
\hline Sterilisasi botol susu & & \\
\hline Baik & 1 & 1,4 \\
Cukup Baik & 34 & 48,6 \\
Tidak Baik & 35 & 50 \\
\hline Cara penyajian makanan & & \\
\hline Memenuhi Syarat & 27 & 38,6 \\
Tidak Memenuhi Syarat & 43 & 61,4 \\
\hline JUMLAH & $\mathbf{7 0}$ & $\mathbf{1 0 0}$ \\
\hline
\end{tabular}

Sumber : Data Primer, 2018

Berdasarkan tabel 1 di atas diketahui bahwa mayoritas ibu balita yang menjadi responden berumur 30-40 tahun, tidak bekerja, berpendidikan SD dan SMP, sumber air bersih yang digunakan untuk membuat susu formula tidak memenuhi syarat, terilisasi botol susu 


\section{Variabel Dependen}

Tabel 2

Distribusi Frekuensi Kejadian Diare Pada Balita Di Desa Duampanua Kecamatan Anreapi Kabupaten Polewali Mandar Tahun 2018.

\begin{tabular}{lcc}
\hline KEJADIAN DIARE & $\mathbf{n}$ & $\mathbf{\%}$ \\
\hline Diare & 49 & 70 \\
Tidak Diare & 21 & 30 \\
\hline Jumlah & $\mathbf{7 0}$ & $\mathbf{1 0 0}$ \\
\hline
\end{tabular}

Sumber : Data Primer, 2018

Berdasarkan tabel 2 diketahui bahwa mayoritas responden memiliki balita yang menderita diare yaitu sebanyak 49 orang.

\section{Analisis Bivariat}

Tabel 3

Analisis Hubungan Variabel Independen Dengan Kejadian Diare pada Balita di Desa Duampanua Kecamatan Anreapi Kabupaten Polewali Mandar tahun 2018.

\begin{tabular}{ccccccc}
\hline VARIABEL & & \multicolumn{3}{c}{ KEJADIAN DIARE } & & p value \\
INDEPENDEN & & YA & TIDAK & & \\
& & $\%$ & n & $\%$ & \\
\hline
\end{tabular}

\begin{tabular}{|c|c|c|c|c|c|}
\hline \multicolumn{6}{|c|}{ Sumber Air Bersih Yang Digunakan Untuk Membuat Susu Formula } \\
\hline Memenuhi Syarat & 4 & 5,7 & 12 & 17,1 & 0,000 \\
\hline $\begin{array}{c}\text { Tidak Memenuhi } \\
\text { Syarat }\end{array}$ & 45 & 64,3 & 9 & 12,9 & \\
\hline
\end{tabular}

\section{Sterilisasi Botol Susu}

Baik 0

0

1

1,4

$\begin{array}{ccccc}\text { Cukup Baik } & 17 & 24,3 & 17 & 24,3 \\ \text { Tidak Baik } & 32 & 45,7 & 3 & 4,3\end{array}$

\begin{tabular}{cccccc}
\hline Cara Penyajian Makanan & & & & \\
\hline Memenuhi Syarat & 16 & 22,9 & 11 & 15,7 & 0,120 \\
Tidak Memenuhi & 33 & 47,1 & 10 & 14,3 & \\
Syarat & & & & & \\
\hline
\end{tabular}

Sumber : Data Primer, 2018

Berdasarkan tabel 3 diatas diketahui bahwa terdapat hubungan yang signifikan antara sumber air bersih yang digunakan untuk membuat susu formula ( $p$ value $=0,000)$, dan sterilisasi botol susu $(p$ value $=0,000)$ terhadap kejadian diare pada balita, dan tidak terdapat hubungan yang signifikan antara cara penyajian makanan $(p$ value $=0,120)$ terhadap kejadian diare pada balita.

\section{PEMBAHASAN}

Hubungan Sumber Air Bersih Yang Digunakan Untuk Membuat Susu Formula Terhadap Kejadian Diare Pada Balita 
Penyebab diare pada manusia erat kaitannya dengan kualitas fisik air yang mereka konsumsi untuk minum dalam kehidupan sehari-hari.

Menggunakan air minum yang tercemar dalam hal ini air yang sudah tercemar dari sumbernya atau pada saat disimpan dirumah dapat menyebabkan diare.

Hal-hal yang perlu diperhatikan dalam penyediaan air bersih adalah :

1. Mengambil air dari sumber air yang bersih

2. Mengambil dan menyimpan air dalam tempat yang bersih dan tertutup, serta menggunakan gayung khusus untuk mengambil air.

3. Memelihara atau menjaga sember air dari pencemaran oleh binatang, anak-anak dan sumber pengotoran. Jarak antara sumber air minum dengan sumber pengotoran, tempat pembuangan sampah dan air limbah harus lebih dari 10 meter.

4. Menggunakan air yang direbus.

5. Mencuci semua peralatan masak dan makan dengan air yang bersih dan cukup (Depkes RI,2000) dalam (Wulandari, 2009).

Berdasarkan Hasil analisis bivariat menunjukkan bahwa kejadian diare dengan kategori air bersih yang digunakan untuk membuat susu formula yang memenuhi syarat terdapat 4 orang $(5,7 \%)$ yang diare dan 12 orang $(17,1 \%)$ tidak diare. Sedangkan dari 54 orang dengan kategori Air bersih yang digunakan untuk membuat susu formula yang tidak memenuhi syarat sebanyak 45 orang $(64,3 \%)$ yang diare dan 9 orang $(12,9 \%)$ tidak diare.

Hasil uji statistik diperoleh nilai $p$ value $=0,000$ lebih kecil dari alpha. Interpretasinya terdapat hubungan yang signifikan antara Sumber air bersih yang digunakan untuk membuat susu formula terhadap kejadian diare pada balita di Desa Duampanua Kecamatan Anreapi Kabupaten Polewali Mandar.

Hal ini sejalan dengan penelitian yang dilakukan oleh Bumulo tentang hubungan sarana penyediaan air bersih dan jenis jamban keluarga dengan kejadian diare pada anak balita di Wilayah Kerja Puskesmas Piloloda Kecamatan Kota Barat Kota Gorontalo, yang menunjukkan bahwa ada hubungan sarana penyediaan air bersih dengan kejadian diare pada balita dengan $p=0,005$ (Bumolo, 2012).
Hal ini juga didukung oleh penelitian Anjar Wulandari yang melihat hubungan faktor lingkungan dan faktor sosiodemografi dengan kejadian diare pada balita di Desa Blimbing Kecamatan Sambirejo Kabupaten Sragen yang dilakukan pada 70 sampel menunjukkan bahwa nilai $p=0,001$ artinya terdapat hubungan antara sumber air dengan angka kejadian diare pada balita (Wulandari, 2009).

Tingginya angka kejadian diare pada responden yang menggunakan air bersih untuk membuat susu formula yang tidak memenuhi syarat yaitu sebanyak 45 responden dikarenakan untuk keperluan minum dan memasak sehari-hari responden tidak ditampung didalam wadah tertutup dan menguras 1-2 kali dalam seminggu sehingga besar kemungkinan untuk terkontaminasi dengan bakteri penyebab kejadian diare. Kemudian untuk keperluan minum keluarga, responden tidak memasak air minum hingga mendidih sehingga mikroorganisme yang ada di dalam air tersebut tidak mati dan menyebabkan kejadian diare.

Adapun responden yang menggunakan sumber air bersih yang tidak memenuhi syarat namun balitanya tidak menderita diare, disebabkan karena responden menampung air yang digunakan untuk keperluan minum dan memasak dalam wadah tertutup, memasak hingga mendidih air untuk keperluan minum dan untuk membuat susu formula, dan jarak antara sumber air dengan tempat pembuangan tinja $\geq 10$ meter.

Menurut Widoyono penyakit diare sebagian besar disebabkan oleh kuman seperti virus dan bakteri.penularan penyakit diare melalui fecal oral terjadi melalui air yang merupakan media utama penularan diare.diare dapat terjadi apabila seseorang menggunakan air minum yang tercemar, baik tercemar dari sumbernya, tercemar selama perjalanan sampai kerumah-rumah atau tercemar pada saat tersimpan dirumah. Pencemaran dirumah terjadi apabila tempat penyimpanan tidak tertutup atau apabila tangan yang tercemar menyentuh air pada saat mengambil air dari tempat penyimpanan (Widoyono, 2008).

Adapun responden yang menggunakan sumber air bersih untuk memnbuat susu formula yang memenuhi syarat namun balitanya tetap menderita diare yaitu karena disebabkan responden melakukan sterilisasi botol susu dengan tidak baik dan cara 
penyajian makanan yang tidak memenuhi syarat.

Air minum yang tercemar adalah penyebab utama penyebaran infeksi terutama diare. Jadi sebaiknya ibu menyimpan air di tempat yang bersih dan tertutup di rumah serta bersihkan wadah air secara rutin. Jangan pergunakan wadah penyimpanan air secara langsung untuk minum. Untuk air yang akan dikonsumsi sebaiknya terlebih dahulu dimasak hingga mendidihsehingga mikroorganisme yang ada di dalam air tersebut mati dan tidak menyebabkan kejadian diare.

\section{Hubungan Sterilisasi Botol Susu Terhadap Kejadian Diare Pada Balita}

Botol susu merupakan sarana tempat berkembang biaknya kuman maupun bakteri karena botol susu sulit dibersihkan. Tindakan ibu dalam sterilisasi botol yang tidak bersih atau sudah dipakai selama berjam-jam dibiarkan dilingkungan terbuka, sering menyebabkan infeksi karena botol dapat tercemar oleh kuman-kuman dan bakteri penyebab diare. Sehingga balita beresiko mengalami diare apabila tindakan sterilisasi botol susu yang dilakukan ibu tidak tepat.

Cara mensterilkan botol susu dapat dilakukan dengan :

1. Cuci tangan sebelum melakukan sterilisasi.

2. Segera setelah selesai memberikan susu formula, botol segera dibersihkan dengan merendam dalam air bersih supaya mudah dibersihkan.

3. Cuci semua peralatan dengan sabun dan air yang mengalir.

4. Cuci dengan sikat botol sampai ke dasar botol.

5. Bagian dalam dan atas botol harus bersih.

6. Rebus botol dalam panci khusus selama \pm 10 menit sampai mendidih. Jika tidak ada panci khusus, panci biasa pun bisa dipakai, alasi dasarnya dengan serbet bersih agar botol susu tidak langsung terkena panas dari dasar panci.

7. Angkat barang-barang dengan jepitan, letakkan ditempat yang bersih, pada waktu disimpan bagian atas botol biarkan tertutup.

8. Simpan botol susu dalam tempat yang steril (Soenardi,2005).

Berdasarkan Hasil analisis bivariat menunjukkan bahwa kejadian diare dengan kategori Sterilisasi botol susu yang baik hanya 1 orang $(1,4 \%)$ tidak diare. Sedangkan dari 34 orang dengan kategori sterilisasi botol susu cukup baik sebanyak 17 orang $(24,3 \%)$ diare dan 17 orang $(24,3 \%)$ tidak diare. Dan dari 35 orang dengan kategori sterilisasi botol susu tidak baik sebanyak 32 orang $(45,7 \%)$ diare dan 3 orang $(4,3 \%)$ tidak diare.

Hasil uji statistik diperoleh nilai $p$ value $=0,000$ lebih kecil dari alpha. Interpretasinya terdapat hubungan yang bermakna antara Sterilisasi botol susu terhadap kejadian diare pada balita di Desa Duampanua Kecamatan Anreapi Kabupaten Polewali Mandar.

Hal ini sejalan dengan penelitian yang dilakukan oleh wibowo yang menunjukkan bahwa adanya hubungan yang signifikan antara proses sterilisasi botol susu dengan kejadian diare pada balita yang mengkonsumsi susu formula (Wibowo,2004).

Hal tersebut juga dibuktikan oleh penelitian Hanifati Sharfina yang menunjukkan bahwa adanya hubungan yang bermakna antara penggunaan botol susu dengan status kejadian diare pada balita ( $p$ value $=0,001)$. Hasil OR yang didapat yaitu 6,476 yang artinya ibu yang menggunakan botol susu yang tidak memenuhi syarat 6,476 kali lebih besar balitanya untuk menderita diare dibandingkan dengan ibu yang menggunakan botol susu yang memenuhi syarat. Mencuci dan mensterilkan botol susu penting dilakukan untuk membunuh semua kuman yang ada (Sharfina, Jurnal, 2016).

Tingginya angka kejadian diare pada responden yang melakukan sterilisasi botol susu tidak baik sebanyak 35 responden dikarenakan, responden melakukan sterilisasi botol susu dengan mencuci botol susu mereka hanya menggunakan sabun saja tidak disikat, tidak dilakukan perebusan atau perendaman botol dengan menggunakan air panas setiap akan digunakan. Kemudian jika tidak dipakai hanya digeletakan di rak piring dan tidak dimasukan ke tempat khusus yang tertutup, sehingga memungkinkan kuman ataupun bakteri kembali menempel pada botol tersebut yang mengakibatkan terjadinya diare.

Sedangkan rendahnya tingkat kejadian diare balita yang menggunakan botol susu disebabkan karena tindakan ibu tentang proses sterilisasi yang sudah cukup baik. Proses sterilisasi botol susu yang baik harus melalui beberapa tahapan diantaranya harus 
menggunakan air mengalir langsung dari kran, menggunakan sabun dan sikat, setelah dicuci botol ditempatkan dalam ruang khusus, bebas dari debu/serangga, dan diletakkan pada ruang yang sirkulasinya segar atau langsung terkena sinar matahari agar bakteri dapat mati.

Pada balita yang menggunakan botol susu, diare dapat disebabkan karena botol susu yang kurang bersih dan mengandung bakteri yang menyebabkan sakit perut dan diare atau karena air susu yang sudah tidak layak lagi dikonsumsi (basi) diberikan oleh ibu atau pengasuh yang kurang teliti. Maka hendaklah berhati-hati dalam memberikan makanan kepada balita, karena pada balita keadaan fisiknya belum begitu kuat untuk mempertahankan keadaan penyakit, sehingga mereka masih sangat rentan terhadap berbagai penyakit (Cita, 2014).

Sistem kekebalan tubuh balita masih sangat lemah sehingga mereka lebih mudah terserang kuman dan bakteri yang pada umumnya tidak berbahaya bagi orang dewasa namun berbahaya bagi balita. Kontaminasi bakteri pada perlengkapan makan/minum balita bisa berakibat diare. Untuk memperkecil risiko ini Sebaiknya ibu setiap selesai memberikan susu formula, botol susu segera disterilkan dengan cara merendam ke dalam air bersih lalu disterilkan menggunakan sabun, disikat kemudian dibilas dengan menggunakan air besih, rebus botol susu untuk menghilangkan noda susu yang ada kemudian simpan ditempat yang steril dan tertutup agar risiko kejadian diare pada balita dapat dihindari.

\section{Hubungan Antara Cara Penyajian Makanan Terhadap Kejadian Diare Pada Balita}

Penyajian makanan matang merupakan rangkaian akhir dari perjalanan makanan. Makanan yang disajikan adalah makanan yang siap dan layak santap dan yang perlu diperhatikan adalah tempat, cara dan prinsip penyajian harus memenuhi persyaratan kesehatan. Adapun kegiatan yang dilakukan yaitu menyimpan makanan dalam wadah yang bersih, meletakkan makanan ditempat yang dingin dan terhindar dari sinar matahari langsung, menjaga makanan agar tidak dijamah oleh hewan dan anak-anak, menjaga piring, panci masak dan peralatan makan agar selalu bersih, mencuci bahan makanan sebelum diolah, mencuci tangan dengan sabun dan air bersih sebelum memasak dan menyajikan makanan (Rahmah, 2006).

Berdasarkan Hasil analisis bivariat menunjukkan bahwa kejadian diare dengan kategori Cara penyajian makanan yang memenuhi syarat terdapat 16 orang $(22,9 \%)$ menderita diare dan 11 orang $(15,7 \%)$ tidak diare. Sedangkan dari 43 orang dengan kategori cara penyajian makanan yang tidak memenuhi syarat sebanyak 33 orang $(47,1 \%)$ menderita diare dan 10 orang $(14,3 \%)$ tidak diare.

Hasil uji statistik dengan diperoleh nilai $p$ value $=0,120$ lebih besar dari nilai alpha . Interpretasinya tidak terdapat hubungan yang bermakna antara cara penyajian makanan terhadap kejadian diare pada balita di Desa Duampanua Kecamatan Anreapi Kabupaten Polewali Mandar.

Tingginya angka kejadian diare pada responden yang tidak melakukan cara penyajian yang memenuhi syarat sebanyak 43 responden dikarenakan selain tidak menyimpan makanan ke dalam lemari, responden juga tidak melakukan sterilisasi botol susu dengan baik sehingga balita menderita diare.

Rendahnya angka kejadian diare pada responden yang memiliki balita pada penelitian ini dikarenakan tindakan ibu tentang cara penyajian makanan sudah baik yaitu dengan mencuci bahan makanan sebelum diolah dan dimakan menggunakan air bersih, menutup makanan yang sudah dimasak menggunakan kain penutup atau tudung saji, tidak menyajikan makanan diatas lantai dalam keadaan terbuka dan juga mencuci tangan menggunakan air bersih dan sabun sebelum memasak.

Pada 11 orang responden yang cara penyajian makanannya memenuhi syarat dan tidak menderita diare karena ibu responden selain cara penyajiannya yang memenuhi syarat, sumber air bersih yang digunakan memenuhi syarat dan melakukan sterilisasi botol susu dengan cukup baik.

Hasil penelitian ini sejalan dengan penelitian Widyana siregar yang menunjukkan bahwa tidak ada hubungan antara kebersihan peralatan makanan, kebersihan bahan makanan dan cara penuajian makanan dengan kejadian diare pada balita. Dengan $p$-value $=0,915$ dan $p$-value $=0,668$.

Hasil penelitian ini tidak sejalan dengan penelitian yang dilakukan oleh Hanifati 
Sharfina yang menunjukkan bahwa ada hubungan antara pengolahan, penyediaan, dan penyajian makanan dengan kejadian diare pada balita ( $\mathrm{p}$-value $=0,001)$. Hasil OR atau besar pengaruh yang didapat yaitu 4,667 yang artinya pengolahan, penyediaan, dan penyajian makanan yang tidak memenuhi syarat 4,667 kali lebih besar untuk menderita diare dibandingkan dengan pengolahan, penyediaan, dan penyajian makanan yang memenuhi syarat (Sharfina, Jurnal, 2016).

Hasil penelitian ini juga tidak sejalan dengan penelitian Hidayanti yang menunjukkan bahwa ada hubungan antara pengolahan, penyediaan, dan penyajian makanan dengan kejadian diare pada balita ( $\mathrm{p}$ value $=0,006, \mathrm{p}<0,05)$ dengan OR 2,222. Higiene sanitasi makanan minuman penting dilakukan untuk mencegah terjadinya kontaminasi yang dapat menimbulkan gangguan kesehatan. Pencemaran dirumah dapat terjadi apabila tempat penyimpanan tidak tertutup dengan baik (Hidayanti, 2012).

Guna mencegah terjadinya risiko kejadian diare pada balita sebaiknya ibu menjaga kebersihan diri saat akan menyiapkan makanan yaitu dengan mencuci tangan menggunakan sabun dan air mengalir dengan menggunakan sabun. Kemudian bahan makanan sebelum diolah hendaknya dicuci terlebih dahulu hingga bersih, makanan yang sudah matang sebaiknya disimpan ditempat yang tertutup untuk menghindari lalat pembawa kuman dan bakteri penyebab diare hinggap dimakanan, sehingga risiko kejadian diare pada balita dapat dihindari.

\section{KESIMPULAN}

Berdasarkan hasil penelitian dan analisis variabel yang diteliti tentang kejadian diare terhadap tindakan ibu pada balita di Desa Duampanua Kecamatan Anreapi Kabupaten Polewali Mandar, maka disimpulkan sebagai berikut : Hasil penelitian menunjukkan bahwa terdapat hubungan signifikan antara tindakan ibu dalam memilih sumber air bersih yang digunakan untuk membuat susu formula dan sterilisasi botol susu terhadap kejadian diare pada balita, namun tidak terdapat hubungan signifikan antara tindakan ibu dalam cara penyajian makanan terhadap kejadian diare pada balita di Desa Duampanua Kecamatan
Anreapi Kabupaten Polewali Mandar Tahun 2018.

\section{SARAN}

Kepada masyarakat pengguna botol susu pada balita diharapkan untuk senantiasa membiasakan mencuci tangan dengan baik dan benar dan selalu memperhatikan kesterilan botol susu balita guna menghindari balita dari resiko kejadian diare.

\section{UCAPAN TERIMA KASIH}

Terima kasih kepada kedua orang tua dan keluarga yang memberikan seluruh bantuan dan dukungan dalam menyelesaikan penelitian ini. Serta Camat Wonomulyo yang telah memberikan izi untuk penelitian ini.

\section{DAFTAR PUSTAKA}

Bumulo, S. 2012. Hubungan Sarana Penyediaan Air Bersih dan Jenis Jamban Keluarga dengan Kejadian Diare pada Anak Balita di Wilayah Kerja Puskesmas Pilolodaa

Cita, Roya.S. 2014. Hubungan Sarana Sanitasi Air Bersih Dan Perilaku Ibu Terhadap Kejadian Diare Pada Balita Umur 10-59 Bulan Di Wilayah Puskesmas Keranggan Kecamatan Setu Kota Tangerang Selatan Tahun 2013. Skripsi. Jakarta. Universitas Islam Negeri Syarif Hidayatullah Jakarta.

Depkes, R. I., 2005. Buku Pedoman Pelaksanaan Program P2 Diare. Jakarta : Ditjen PPM dan PL.

Dinas Kesehatan Kabupaten.2015. Profil kesehatan Polewali Mandar 2016. Polewali Mandar.

Dinas Kesehatan Kabupaten.2016. Rekapitulasi Penderita Diare Menurut Golongan Umur, Kabupaten Polewali Mandar Januari Sampai Desember 2016. Polewali Mandar.

Hidayanti R. 2012. Faktor risiko diare di Kecamatan Cisarua, Cigudeg dan Megamendung Kabupaten Bogor tahun 2012. Skripsi. Depok: Universitas Indonesia.

Kementerian Kesehatan RI. 2015. Profil Kesehatan Indonesia 2014. Jakarta. 
Notoatmodjo S. 2003. Ilmu Kesehatan Masyarakat Prinsip-prinsip Dasar. Jakarta: PT Rineka Cipta.

Patmawati, Kadrianti. 2016. Faktor Risiko Lingkungan Fisik rumah dengan kejadian ISPA oada balita di kelurahan Takatidung polewali mandar. Unnes journal of public health. 5 (4) : 324-329

Peraturan Menteri Kesehatan RI No. 492 /MENKES/PER/IV/2010 tentang persyaratan kualitas air minum.

Prita, Nimas. 2014. Hubungan Antara Perilaku Ibu dan Kejadian Diare Pada Balita di Wilayah Kerja Puskesmas Sanitar Hilir. Skripsi. Pontianak. Universitas Tanjungpura.

Rahmah, Sitti. 2006. Hubungan perilaku ibu yang memiliki anak balita usia 2-5 tahun terhadap kejadian diare di Kecamatan Suka Makmur Kabupaten Aceh besar tahun 2006. Tesis. Medan. Universitas Sumatera Utara.

Riset Kesehatan Dasar. 2013. Badan Penelitian Dan Pengembangan Kesehatan Kementerian Kesehatan RI. Jakarta

Sharfina, Hanifati, dkk. 2016. Pengaruh Faktor Lingkungan Dan Perilaku Terhadap Kejadian Diare Pada Balita Di Wilayah Kerja Puskesmas Sungai Tabuk Kabupaten Banjar.
Jurnal publikasi kesehatan masyarakat indonesia, vol.3 no.3 Desember 2016. Universitas lambung mangkurat.

Soenardi, T, 2005. Cara Membersihkan Botol Susu. Penerbit Yayasan Bina pustaka. Jakarta.

Sukardi. 2016. Faktor-Faktor Yang Berhubungan Dengan Kejadian Diare Pada Balita 6-59 Bulan Di Wilayah Kerja PuskesmasPOASIA tahun 2016. Skripsi. Manado. Universitas Halu Oleo.

Wibowo, T. dkk. 2004. Faktor-Faktor Risiko Kejadian Diare Berdarah pada Balita di Kabupaten Sleman. Jurnal Berita Kedokteran Masyarakat. Vol. 20. No.1. maret 2004 : 4148.

Widjaja, 2002. Mengatasi Diare dan Keracunan pada Balita. Jakarta : Kawan Pustaka.

Widoyono. 2008. Penyakit Tropis Epidemiologi, Penularan, Pencegahan dan Pemberantasannya. Surabaya: Erlangga.

Wulandari, Anjar P. 2009. Hubungan Antara Faktor Lingkungan Dan Faktor Sosiodemografi Dengan Kejadian Diare Pada Balita Di Desa Blimbing Kecamatan Sambirejo Kabupaten Sragen Tahun 2009. Skripsi. Surakarta. Universitas Muhammadiah Surakarta. 
